\title{
Social \& Financial Inclusion Activities And It's Impact On Improving The Welfare Of Society
}

\author{
Hermien Triyowati ${ }^{1}$, Yolanda Masnita ${ }^{2}$ and Khomsiyah $^{3}$ \\ \{hate_usakti@yahoo.com $\left.{ }^{1}\right\}$ \\ 1,2,3 Trisakti University, Jl. Kyai Tapa No.1, Grogol Jakarta 11440, Indonesia
}

\begin{abstract}
BAZNAS (National Zakat Agency) as one of the national zakat management institutions in Indonesia, created the Zakat Community Development (ZCD) program, and began to be implemented since 2010. The objective of ZCD program is to improve the economic, social and cultural conditions of the community, through empowering communities in the social, economic and spiritual fields, complete with the provision of access to these needs, by directing communities to have the capability to live independently this is known as an inclusion activity, on the social, economic and financial sector. The object of the study was 'beneficiaries of the ZCD program' in seven (7) poor regions. This study aims to determine the extent to which 'success' of the ZCD program implementation, and its impact on community welfare, ultimately leads to poverty alleviation. Using the method of path analysis with mediation, as well as secondary data related to several variables of 'community welfare' (education, health, community through democracy development of MSEs, unemployment and income), the study concludes the positive and significant impacts of the implementation of this program on health, the development of MSEs and GDRP, which also proves significant as mediation towards poverty reduction.
\end{abstract}

Keywords: Financial inclusion, Society, Welfare, Zakat Community Development, MSEs

\section{Introduction.}

Improving people's welfare cannot be separated from how society develops. A prosperous society is a society that meets the needs, both basic needs (food, clothing, housing, education, and health), social and political needs, and spiritual needs. Especially in disadvantaged communities (poor average population, low level of education, low level of health, high crime rate, etc.), Must get help, either from government or private, to improve their welfare through community development activities.

In essence, capable Muslim societies, have a way to participate in improving the welfare of the people, through the obligation to provide part of their income in the form of Zakat, Infaq and Sedekah (ZIS), to be given to the poor, where the collection and distribution of these funds in Indonesia is managed by BAZNAS. Zakat means the obligation for certain assets, charged to the people (Muslims) who are able, at certain times, to be given to the people who are entitled to receive (seven groups), with certain conditions as well. Infaq is removing part of the property, for something that is ordered by Allah, for example to provide a living for his family. Sedekah can be interpreted as issuing property that is not obligatory, in the way of Allah, as proof of honesty or truth of one's faith.

BAZNAS is an institution that performs ZIS management nationally, which performs planning, collection, distribution, and utilization of ZIS; as well as the control and reporting of the accountability of ZIS management (Yuswar, et al. 2015). He stated that, the distribution of ZIS to eligible groups of poor people has proven to influence the regional economy of Jakarta 
(Capital Special Region). ZIS distribution for education funds, in the form of student scholarships amounting to IDR $12,616 \mathrm{M}$, and for health funds amounting to IDR $10,893 \mathrm{M}$, causing Jakarta's regional output to increase by IDR 43,849 M, this shows the magnitude of the impact of ZIS distribution on the regional economy (Gross Regional Domestic Product/GRDP) of Jakarta as a whole. (Yuswar, et.al. 2014). On the other hand, in practice, the distribution of ZIS in Indonesia has not been managed as required in Law No. 23 of 2011. The distribution of ZIS is still intended to address the problem of basic needs, which means that it has not encouraged the emergence of economically independent societies (Mintarti, Nana, 2016).

By paying attention to this fact, BAZNAS, develops Zakat Community Development (ZCD) program that plays a role in the distribution of ZIS, through community empowerment, and is expected to encourage the emergence of self-reliance. The ZCD program includes community development activities in various aspects of life, in order to create a society that has empowerment in education, health, economics and religious life, which is a key element and interconnected with one another. This program has been started since 2010, but is still limited to 43 villages, located in nine provinces in Indonesia, especially areas with high poverty levels, exceeding the national poverty level (BAZNAS, 2016).

Moreover, the targets of the ZCD program include two community goals, namely (1) the region-based community (rural, urban, and coastal) and (2) the community-based social groups, which includes vulnerable groups and certain entity groups such as orphanage. To become the target of the ZCD program, 'the region-based community' must meet the following requirements, such as (1) the number of poor people is more than $50 \%$, and (2) the level of food insecurity / creed / natural disaster is high. While the requirements of 'community-based social groups' are (1) consisting of those who meet the criteria of poor people, converts/mualaf, and the recipient of zakat (mustahik) and (2) communities that have the goal of realizing community welfare and poverty alleviation.

Based on this fact, the purpose of the study was to determine the role of the ZCD program for social, economic and financial activities, in improving the welfare of the poor people (Dhuafa community), in Indonesia.

\section{Material And Method}

\subsection{Community Development and Community Based Empowerment}

Community development is the process of independent community efforts, integrated with government authorities, to improve socio-economic and cultural conditions of the community, integrate society into national life and encourage more optimal community contributions to national progress (Hayden Woods, et. al. 1979; Karen Miller, 2017). This means community development is a program that aims to accelerate poverty alleviation based on developing community independence through community capacity building, community participation and institutional development. (Rahardi, Dicky, 2006; Teresa Cunha Ferreira, 2018).

Community development is also defined as a foundation of professional practice and academic discipline that promotes the participation of democracy, sustainable development, human rights, economic opportunities, equality of rights and social justice,through organizations, education, community empowerment, based on their location, interest or identity, either in the city or village (Internal Association for Community Development/IACD, Eilidh Finlayson, et.al. 2018, www.iacdglobal.org). 
Based on these statements, community development is very loaded with various empowerment efforts, the ultimate goal of which is to inspire and motivate them to be able to fight their own weaknesses, so that they can improve their standard of living towards a decent life.

\subsection{ZCD as Social - Economic - Financial Inclusion, ZCD Principles}

Zakat Community Development (ZCD) is one of the ZIS distribution programs, with a capability approach, in accordance with the wisdom and laws of Islam. People who have capabilities, are the ones that emit at- takaful alijtimaa'i (mutual responsibility in social activities), including at-takaful i'tishaadi, (mutual responsibility in economic activities), and at-takaful ma'asyi (mutual responsibility in tackling the lives of disadvantaged groups, such as the poor, the sick, the elderly, the refugees, and others).

ZCD is a community development program that integrates social aspects (education, health, religion, environment, etc.) and comprehensive economic-financial aspects, with major funding sourced from ZIS, and aims to create a society that has empowerment in education, health, economics and religious life, referred to as Caturdaya Masyarakat Sejahtera dan Mandiri / Four power Prosperous and Independent Society (Mintarti Nana, 2016; Muhammad Kashif, et.al. 2018). Thus, because the ZCD Program is implemented to help the community, does not burden the recipient, and there is no element of coercion or punishment, the ZCD program can be categorized as an inclusion activity, in the social, economic and financial fields.

In its implementation, the ZCD program integrates six (6) principles, namely, (a) Community-based principles: the objectives of the ZCD program are 'beneficiaries', collected in geographical areas due to special conditions, and implemented in various forms of mutually agreed activities; (b) Islamic Sharia Principles: the ZCD program is implemented based on the provisions of Islamic law in zakat distribution; (c) Principle of participation: the ZCD program is implemented by directly involving 'beneficiaries', from the planning stage to the implementation; (d) Principle of benefit: the ZCD program provides 'material and nonmaterial' added value, as much as possible to beneficiaries; (e) Principle of sustainability: the ZCD program is carried out in stages over a period of time, and with a variety of interrelated activities, towards achieving program objectives; and (f) Principle of synergy: the ZCD program is an open program for various parties involved, both in funding and management, as a form of cooperation in virtue and piety (BAZNAS, 2017).

Thus, it can be stated that, the success of ZCD program, is depend on the capabilities of the agents of development, both intellectually and personality, also depends on their understanding of Sharia laws and rules, in the Islamic religion.

\subsection{Social Welfare and Poverty}

Social welfare is defined as the condition of a prosperous society, with basic needs being met, including physical, mental, emotional and economic needs. Improving social welfare, is a planned process carried out by individuals, communities, social institutions, and governments, through the provision of services and social benefits, realizing harmonization of social relations between individuals and groups, with the aim of achieving maximum capacity development, towards prosperity that is in accordance with community needs (Suharto, Edi 2006, 2009). Thus, social welfare is measured from the level of life, fulfillment of basic needs, quality of life and human development. For this purpose, a capability approach is needed in determining living standards (Sen Amartya, 2002; Lauren Bradford, 2017). 
Human development, can be measured by the Human Development Index (HDI). This index is formed by 3 (three) basic dimensions, namely: (a) Long and healthy life, measured by 'the life expectancy at birth'; (B) Knowledge, measured by 'the expected years schooling' and 'means years schooling'; (c) Decent standard of living, measured by 'per capita expenditure' or income per capita (Human Development Report, 2016).

In addition, there are four main approaches to understanding poverty, namely (1) Approach to basic needs, states that poverty is caused by the lack of public access to basic needs; (2) The income approach, states that poverty is caused by low control of productive assets and instruments (land and agricultural land / plantations), which directly affects the income of the community; (3) Human capability approach, states that poverty is caused by limited basic skills, such as the ability to read and write to perform a minimum function in society, which causes 'closed opportunities' for poor people to be involved in decision making; and (4) Objective and subjective approaches. An objective approach (welfare approach), emphasizes normative assessment and conditions that must be met to get out of poverty. The subjective approach assesses poverty based on the opinions of the poor themselves (Bappenas, 2008; Isaac Lyne, et.al, 2018).

\subsection{Hypothesis, Research Variables and Conceptual Framework.}

Based on this explanation, it can be concluded that, the ZCD program, is the right tool to improve the welfare of the community in the target area. Through various empowerments to beneficiary communities, it is expected to improve their quality of life. The success of this program will be seen from the performance of various fields of empowerment carried out.

So the hypothesis of this study are: 'the implementation of the ZCD program, improving the welfare of the community, includes improvements in the fields of education, health, democracy, micro and small enterprises; increase in GRDP and decrease in unemployment and poverty' Thus, the conceptual framework of this study is presented as follows:

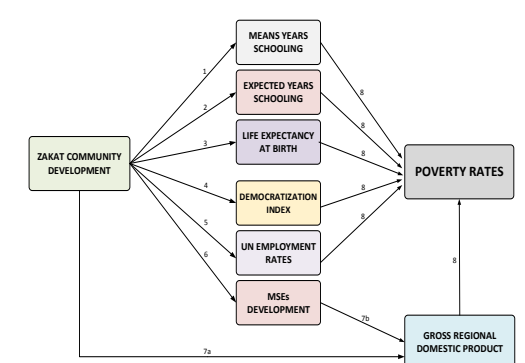

Fig. 1. Conceptual Framework.

So, the variables and indicators of research can be determined as follows:

1. Education variable - improvements in education, demonstrated by changes in community behavior, in an effort to improve the quality of education, as measured by 'means years schooling' / MYS and 'expected years schooling' / EYS.

2. Health variable - improvement in the health sector, is shown by changes in community behavior towards a healthier life, measured by health improvements where people can survive for longer periods of time (Life expectancy at birth / Lifex). 
3. Economics variable: economic improvement, demonstrated by public awareness to improve the quality of economic life, as measured by community involvement in productive economic activities (micro and small enterprises development / dMSEs).

4. Spiritual variable: involvement in the spiritual field, impacts on changes in people's behavior themselves, such as, (a) changes in people's behavior who are 'lazy to work', to be a motivated society to find work, as measured by the decrease in the number of unemployed (Unemp); (b) changes in people's behavior to engage in community activities, such as democratic activities, as measured by the Indonesia democratic index (IDI).

\subsection{Methods of Analysis and Research Model.}

The research design used descriptive causality, aimed to describing and measuring the influence of a causality relationship from various research variables. This study used secondary data, taken from the publication of BAZNAS Annual Report, Puskas-BAZNAS, ZCD Statistics, Indonesian Statistics and Regional in Figures, Report on the Human Development Index of the Indonesia Millennium Development Goals, for the period 20112016.

In accordance with the availability of data, the seven selected study areas are: (1) Bandung District (West Java), (2) Sukabumi District (West Java), (3) Lombok Province (West Nusa Tenggara), (4) East Kutai District (East Kalimantan), (5) Gorontalo Province (North Sulawesi), (6) Aceh Province (North Sumatra) and (7) Siak District (Riau).

Several models, as well as statistical tools used as follows:

Model 1: the relationship between the exogenous variable ZCD, which directly affects several endogenous variables: MYS, EYS, Lifex, IDI, Unemp, GDRB and dMSEs. In this model, simple linear regression is used, in order to test the relationship significance (t-test), model accuracy test $\left(R^{2}\right)$ and calculate the direct effect (standardized coefficient $\beta$ ). Some variables that are not significance, will be excluded from the model. The several Simple Linear Regression Model are presented as follows:

1. MYS $=a+b_{1} * Z C D+e_{1}$

2. $\mathrm{EYS}=\mathrm{c}+\mathrm{d}_{1} * \mathrm{ZCD}+\mathrm{e}_{2}$

3. Lifex $=\mathrm{f}+\mathrm{g}_{1} * \mathrm{ZCD}+\mathrm{e}_{3}$

4. Unemp $=\mathrm{h}+\mathrm{j}_{1} * \mathrm{ZCD}+\mathrm{e}_{4}$

5. IDI $=\mathrm{k}+\mathrm{l}_{1} * \mathrm{ZCD}+\mathrm{e}_{5}$

6. dMSEs $=\mathrm{o}+\mathrm{q}_{1} * \mathrm{ZCD}+\mathrm{e}_{6}$

7. a. $\mathrm{GRDP}=\mathrm{m}+\mathrm{n}_{1} * \mathrm{ZCD}+\mathrm{e}_{7 \mathrm{a}}$

b. $\mathrm{GRDP}=\mathrm{o}+\mathrm{p}_{1} * \mathrm{dMSEs}+\mathrm{e}_{7 \mathrm{~b}}$

Model 2: the relationship between some endogenous variables, i.e. MYS, EYS, Lifex, IDI, Unemp, GRDP and dMSEs, against the impact variable POV. In this model, multiple linear regression is used, in order to test the relationship significance (t-test), model accuracy test $\left(\mathrm{R}^{2}\right.$ adjusted) and calculate the direct effect (standardized coefficient $\beta$ ). Some variables that are not significance, will be excluded from the model, by stimming technique, which is started by selecting the variable with the biggest error rate, up to all variable significance. The Multiple Linear Regression Equation, presented as follows:

8. $\mathrm{POV}=\mathrm{q}+\mathrm{r}_{1} * \mathrm{ZCD}+\mathrm{r}_{2} *$ MYS $+\mathrm{r}_{3} *$ EYS $+\mathrm{r}_{4} *$ Lifex $+\mathrm{r}_{5} *$ IDI $+\mathrm{r}_{6} *$ Unemp $+\mathrm{r}_{7} * \mathrm{dMSEs}+$ $\mathrm{r}_{8} * \mathrm{GRDP}+\mathrm{e}_{8}$ 
Model 3: according to research objectives, formulated causality structural equations, from exogenous variable $\mathrm{ZCD}$, to $\mathrm{POV}$ impact variable, through some endogenous variables MYS, EYS, Lifex, IDI, Unemp, GDRB and dMSEs, at which point some endogenous variables serves as a mediation variables. The statistical tool used is path analysis method with mediation.

In path analysis, there are path coefficients, showing the effect of exogenous variables on endogenous variables. This is the value of standardized coefficient $\beta$, as a result of regression analysis between these variables. Based on path coefficients, some structural causal equations are made. This equation is built on theoretical studies, and explains the causal linkages of each endogenous variable uniquely, whose circumstances are determined by a set of exogenous variables. Several Structural Causality Equations are presented as follows:

1. $Z_{\mathrm{POV}}=\rho_{\mathrm{MZ}} * \mathrm{Z}_{\mathrm{ZCD}}+\rho_{\mathrm{PvM}} * \mathrm{Z}_{\mathrm{MYS}}+\mathrm{e}_{1}$

2. $Z_{\mathrm{POV}}=\rho_{\mathrm{EZ}} * \mathrm{Z}_{\mathrm{ZCD}}+\rho_{\mathrm{PvE}} * Z_{\mathrm{EYS}}+\mathrm{e}_{2}$

3. $Z_{\mathrm{POV}}=\rho_{\mathrm{LZ}} * Z_{\mathrm{ZCD}}+\rho_{\mathrm{PvL}} * Z_{\mathrm{Lifex}}+\mathrm{e}_{3}$

4. $Z_{\mathrm{POV}}=\rho_{\mathrm{IZ}} * \mathrm{Z}_{\mathrm{ZCD}}+\rho_{\mathrm{PvI}} * \mathrm{Z}_{\mathrm{IDI}}+\mathrm{e}_{4}$

5. $Z_{\mathrm{POV}}=\rho_{\mathrm{UZ}} * \mathrm{Z}_{\mathrm{ZCD}}+\rho_{\mathrm{PvU}} * \mathrm{Z}_{\mathrm{Unemp}}+\mathrm{e}_{5}$

6. $Z_{\mathrm{POV}}=\rho_{\mathrm{PrZ}} * \mathrm{Z}_{\mathrm{ZCD}}+\rho_{\mathrm{PvPr}} * \mathrm{Z}_{\mathrm{GRDP}}+\mathrm{e}_{6}$

7. $Z_{\mathrm{POV}}=\rho_{\mathrm{MsZ}} * Z_{\mathrm{ZCD}}+\rho_{\mathrm{PvMs}} * Z_{\mathrm{dMSEs}}+\mathrm{e}_{7}$

8. $Z_{\mathrm{GRDP}}=\rho_{\mathrm{MsZ}} * \mathrm{Z}_{\mathrm{ZCD}}+\rho_{\mathrm{GrMs}} * \mathrm{Z}_{\mathrm{dMSEs}}+\mathrm{e}_{8}$

Furthermore, according to the purpose of the study, the total effect of exogenous variables will be calculated on the impact variable, either directly (DE), or indirectly through mediating variables (IE), thus TE $=\mathrm{DE}+\mathrm{IE}$. As an example:

- The direct effect (DE) of the exogenous variable ZCD, in the POV variable, is calculated by squaring the path coefficient value of ZCD against POV, thus

$\mathrm{DE}=(\rho \mathrm{PvZ})^{2}$.

- The Indirect effects (IE) of exogenous variables ZCD, on POV variables, through endogenous variables (Lifex) as mediating variables, calculated from the multiplication of = [ZCD path coefficient on POV] $x$ [ZCD path coefficient on Lifex] $x$ [correlation coefficient between Lifex and POV], thus: $\mathrm{IE}=(\rho \mathrm{PvZ}) \times(\rho \mathrm{PvL}) \times\left(\mathrm{r}_{\mathrm{LPv}}\right)$

\section{Result And Discussion}

Prior to data processing, secondary data quality testing with Kolmogorov Smirnov technique (K's test) should be performed, as a prerequisite for data processing by Ordinary Least square method, such as regression analysis and path analysis. The test results show that, for all data, the value of K's more than 0.05 , this means there is no significant difference between the data to be tested with normal raw data. In other words all data tested is normally distributed. Then, must be searched the relationship between variables $\left(\mathrm{r}_{\mathrm{yx}}\right)$, by calculating the correlation coefficient among several variables (see Appendix).

In addition, the results of data processing, in Model-1 (equation no: 1 to 6) with simple linear regression techniques, are evidence that the MYS, EYS and Unemp variables are not significant $(\alpha>0.10)$, so they must be removed from the model. Furthermore, the results of data processing in Model-1 and Model-2 with multiple linear regression (equations no: $7 \mathrm{a}, 7 \mathrm{~b}$ and 8), prove that IDI and dMSEs variables are not significant, so the first stimming process is performed, by issuing IDI variables (variables with biggest error rate). The results of the first stimming process showed that there was still one insignificant variable, namely dMSEs, so the 
second stimming process was performed, by issuing the dMSEs variable, from the model. The results of this process are all variables, proven to be statistically significant (see Table 1).

Table 1. The Result of Data Processing.

\begin{tabular}{|c|c|c|c|}
\hline $\begin{array}{l}\text { Structural } \\
\text { Relationships }\end{array}$ & $\begin{array}{l}\text { Stand. Coef. } \beta \text { (Path } \\
\text { Coef.) }\end{array}$ & $\rho$ - Value & $\begin{array}{l}\text { Coef. } \\
\left(\mathrm{r}_{\mathrm{yx}}\right)\end{array}$ \\
\hline \multicolumn{4}{|c|}{ Simple and Multiple Linear Regression: equations no 1 to 6 and no.7a,7b } \\
\hline 1. $\mathrm{ZCD}==>\mathrm{MYS}$ & $\rho \mathrm{MZ}=-0.246$ & 0.116 & -0.246 \\
\hline 2. $\mathrm{ZCD}==>\mathrm{EYS}$ & $\rho \mathrm{EZ}=0.020$ & 0.899 & 0.020 \\
\hline 3. $Z C D=\Rightarrow$ Lifex & $\rho L Z=0.275$ & 0.078 & 0.275 \\
\hline 4. $\mathrm{ZCD}==>$ Unemp & $\rho \mathrm{UZ}=-0.083$ & 0.603 & -0.083 \\
\hline 5. $\mathrm{ZCD}==>$ IDI & $\mathrm{oIZ}=0.292$ & 0.061 & 0.313 \\
\hline 6. ZCD $==>$ dMSEs & $\rho \mathrm{MsZ}=0.313$ & 0.044 & 0.292 \\
\hline 7.a. $\mathrm{ZCD}==$ & $\rho \mathrm{GrZ}=0.706$ & 0.000 & 0.626 \\
\hline 7.b.dMSEs ==> GRDP & $\rho \mathrm{GrMs}=0.254$ & 0.049 & -0.117 \\
\hline
\end{tabular}

Conclusion: MYS, EYS and Unemp variables are not statistically significant, and must be excluded from the model.

\begin{tabular}{llll}
\multicolumn{5}{l}{ Multiple linear Regression: equations no. 8. } \\
\hline - ZCD ==> POV & $\rho \mathrm{PvZ}=-0.621$ & 0.005 & -0.445 \\
- Lifex ==> POV & $\rho \mathrm{PvL}=-0.459$ & 0.049 & -0.497 \\
- IDI ==> POV & $\rho \mathrm{PvI}=-0.226$ & 0.284 & -0.676 \\
- dMSEs ==> POV & $\rho \mathrm{PvMs}=0.169$ & 0.187 & -0.066 \\
- GRDP ==> POV & $\rho \mathrm{PvG}=0.503$ & 0.052 & -0.129
\end{tabular}

Conclusion: the IDI and dMSEs variables are not significant, so trimming process -1 it is done, by issuing the IDI variable (variable with the biggest error rate)
- $\mathrm{ZCD}==>$ POV
$\rho P v Z=-0.772$
0.000
$-0.445$
- Lifex ==>POV
$\rho \mathrm{PvL}=-0.661$
0.000
$-0.497$
- dMSEs ==> POV
$\rho \mathrm{PvMs}=0.210$
0.089
$-0.066$
- GRDP ==> POV
$\rho \mathrm{PvGr}=0.709$
0.000
$-0.129$

Conclusion: the dMSE variable is not significant, then the trimming process - II is done, by issuing the dMSEs variable

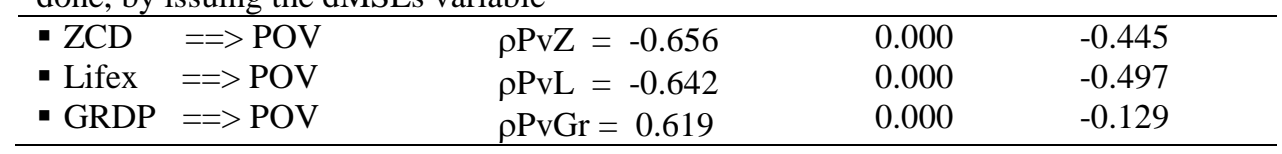

Source: secondary data, processed.

Based on the results of data processing, can only create three path diagrams, especially from the relationship of causality among variables that proved significance, presented in Figure.2. 


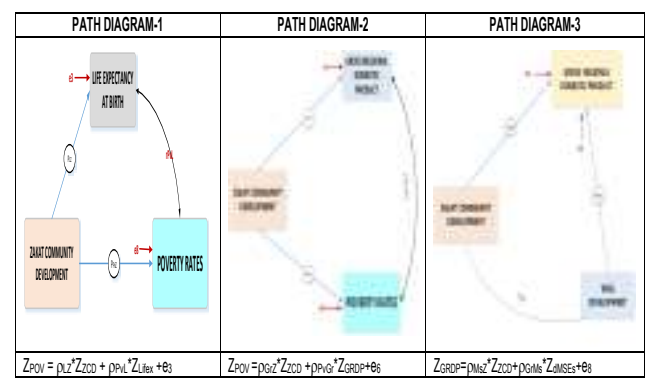

Fig.2. Path Diagram and Structural Causality Equation.

Then from the findings of the three (3) path diagrams, can be calculated, the total impact both directly and indirectly of the implementation of the ZCD program, on poverty, the development of MSEs and GRDP (see table 2.)

Table 2. Calculation of the Total Effect

\begin{tabular}{|c|c|c|}
\hline $\begin{array}{l}\text { Path Diagram }-1 . \\
Z C D==>P O V \\
Z C D==>\text { Lifex } \\
Z C D==>\text { Lifex }==>\text { POV }\end{array}$ & $\begin{array}{l}D E=\left(\rho_{P V Z}\right)^{2}=(-0.656)^{2} \\
D E=\left(\rho_{L Z}\right)^{2}=(0.275)^{2} \\
I E=\left(\rho_{\text {PVZ }}\right) \times\left(\rho_{L Z}\right) \times\left(r_{\text {PVL }}\right)\end{array}$ & $\begin{array}{l}\text { Total Effect: } \\
=0.4303 \\
=0.0756 \\
=0.0896 \\
=0.5955=59.55 \%\end{array}$ \\
\hline $\begin{array}{l}\text { Path Diagram -2. } \\
Z C D==>P O V \\
Z C D==>G R D P \\
Z C D==>G R D P==>P O V\end{array}$ & $\begin{array}{l}D E=\left(\rho_{\text {PVZ }}\right)^{2}=(-0.656)^{2} \\
D E=\left(\rho_{\text {GrZ }}\right)^{2}=(0.706)^{2} \\
I E=\left(\rho_{\text {PVZ }}\right) \times\left(\rho_{\text {G }}\right) \times(\text { P PVGr })\end{array}$ & $\begin{array}{l}=0.4303 \\
=0.4984 \\
=0.0597 \\
=0.9884=98.84 \%\end{array}$ \\
\hline $\begin{array}{l}\text { Path Diagram -3. } \\
Z C D==>\text { GRDP } \\
Z C D==>d M S E s \\
Z C D==>d M S E s==>\text { GRDP }\end{array}$ & $\begin{array}{l}D E=(\rho Z G r)^{2}=(0.706)^{2} \\
D E=(\rho \text { Msz })^{2}=(0.313)^{2} \\
I E=\left(\rho_{\text {ZGr }}\right) \times\left(\rho_{\text {MSZ }}\right) \times\left(r_{\text {MGG }}\right)\end{array}$ & $\begin{array}{l}=0.4984 \\
=0.0645 \\
=(0.0072) \\
=0.5557=55.57 \%\end{array}$ \\
\hline
\end{tabular}

\section{Conclusion}

First, from the seven study areas selected as recipients of the ZCD program, Bandung Regency and Gorontalo were the highest beneficiaries of the 'ZCD program', compared to other regions. In this case, Gorontalo province, is the region with the highest poverty rate in Indonesia.

Second, based on the description of community expenditure in the study area, it shows that spending on smoking is higher than spending on other higher-quality living needs, such as for health, education and public housing. This situation shows that their motivation is still low, towards a better life. Third, the empirical findings show several facts, as follows:

(i) Directly, the implementation of the ZCD program, in the study area, has a positive and significant impact on (a) public health level $=27.5 \%$, (b) public awareness through democratic activities $=29.2 \%$, (c) business, through micro and small business development $=$ $31.3 \%$.

(ii) The total effect of the ZCD program, directly and indirectly through micro and small business development activities, affects the increase in GRDP with an effect of $55.57 \%$.

(iii) The total effect of the ZCD program, directly and indirectly, has an impact on poverty reduction, through health improvements of $59.55 \%$, and through increasing GRDP of $98.84 \%$. 
(iv) In fact, the impact of the implementation of the ZCD program, on poverty reduction, is greater through empowerment activities in the health sector, and the development of micro and small enterprises. This fact, needs the attention of stakeholders, to optimize the ZCD activities in both fields.

\section{Limitations And Further Research}

For the purpose of refining the ZCD program, it is recommended for other researchers to conduct further studies on the implementation of the ZCD program, using primary data, to find out 'the extent to which the performance' of implementing the G-20 principles, as well as the principles of ZCD programs that have defined by BAZNAS. This research is needed to perfect the implementation of ZCD program, so that the purpose of ZCD program is achieved, and for the sustainability of ZCD program in the future.

\section{Acknowledgements.}

We are grateful to Ministry of Research Technology and Higher Education Republic of Indonesia, Dean of Faculty of Economics and Business, Trisakti University, for the opportunity as well as the advice given for this research. We are also grateful to our colleagues for their suggestions and comments. The various errors that exist are our responsibility.

\section{References}

[1] Bappenass, (2008), Evaluasi Program Penanggulangan Kemiskinan Perkotaan (Evaluation of the Urban Poverty Reduction Program), Laporan Akhir / Final Report,http://perpustakaan.bappenas.go.id/lontar/file?file=digital/114040\%5B_Konten_\%5D-M.88\%20Judul\%20dan\%20Daftar\%20Isi0001.pdf

[2] BAZNAS, (2016), Statistics of Zakat Community Development Beneficiaries, Puskas BAZNAS, Official News Center of Strategic Studies, The National Board of Zakat, The Republic of Indonesia.

[3] BAZNAS, (2017), Caturdaya Masyarakat Sejahtera dan Mandiri, (Four power Prosperous and Independent Society), www.baznas.or.id.

[4] Eilidh Finlayson, Michael James Roy, (2018), Empowering communities? Exploring roles in facilitated social enterprise, Social Enterprise Journal.

[5] Hayden Woods, John, FRSC and Harold Coward, (1979) The Importance and Relevance of the Humanities in the Present Day, IX, 107, edited, Waterloo, Wilfrid Laurier University Press.

[6]

https://www.researchgate.net/.../14354763_Empowerment_theory_research_and_app lication

[7] https://doi.org/10.1108/SEJ-04-2018-0035

[8] Human Development Report, (2016) Human Development for Everyone Briefing note for countries on the 2016.

[9] http://www.undp.org/content/undp/en/home/librarypage/hdr/2014-humandevelopment-report.html.

[10] Isaac Lyne, Chanrith Ngin, Emmanuel Santoyo-Rio, (2018) Understanding social enterprise, social entrepreneurship and the social economy in rural Cambodia, Journal of Enterprising Communities: People and Places in the Global Economy, Vol. 12 Issue: 3, pp.278-298, 
[11] https://doi.org/10.1108/JEC-11-2016-0041

[12] Karen Miller, (2017) Exploring Rural Public Library Assets for Asset-Based Community Development, in Brian Real (ed.) Rural and Small Public Libraries: Challenges and Opportunities (Advances in Librarianship, Volume 43) Emerald Publishing Limited, pp.61 - 96

[12] Lauren Bradford, (2017) Nonprofit Social Responsibility and Sustainability: Engaging Urban Youth through Empowerment, in Donnalyn Pompper (ed.) Corporate Social Responsibility, Sustainability, and Ethical Public Relations (The Changing Context of Managing People, Volume ) Emerald Publishing Limited, pp.53 - 88. Law No. 23, article

(2011)OntheManagementof.Zakat,http://pusat.baznas.go.id/wpcontent/perpu/UndangU ndang\%20No\%2023\%20Tahun\%202011\%20tentang\%20Pengelolaan\%20Zakat.pdf

[13] Mintarti Nana, (2016) Zakat Community Development, Artikel, Berita /by baznasjabar , 2016.

[14] Muhammad Kashif, Khurrum Faisal Jamal, Mohsin Abdur Rehman, (2018) The dynamics of Zakat donation experience among Muslims: a phenomenological inquiry, Journal of Islamic Accounting and Business Research, Vol. 9 Issue: 1, pp.45-58,

[15] https://doi.org/10.1108/JIABR-01-2016-0006

[16] Rahardi, Dicky, (2006), Science for Humanity: An Effort to Humanize Human

[17] www.statisticapedia.com../apakah-community-development-itu.ht.

[18] Sen, Amartya, (1992), Inequality Reexamined. New York Oxford: Russell Sage Foundation Clarendon Press Oxford University Press. ISBN 9780198289289. Also printed as: Sen, Amartya, (2003), Oxford Scholarship Online. Oxford University Press. https://dx.doi: 10.1093/0198289286.001.0001

[19] Sen, Amartya, (2002), Rationality and Freedom. Cambridge, MA: Belknap Press. ISBN 9780674013513.

[20] Sri Indarti, (2018), The Role of Corporate Social Responsibility (CSR) toward the development Micro and Small and Entrepreneurs Using Partnership and Community Development Program (PKBL) in Pekanbaru, International Journal of Law and Management, Vol. 60 Issue: 1, pp.79-86, https://doi.org/10.1108/IJLMA-12-2016-0167

[21] Suharto Edi, (2006), Membangun Masyarakat Memberdayakan Rakyat: Kajian Strategis Pembangunan Kesejahteraan Sosial dan Pekerjaan Sosial (Developing Community Empowering People: Strategic Analysis on Social Welfare Development and Social Work) (second edition), Bandung: Refika Aditama.

[22] Suharto Edi, (2009), Kemiskinan dan Perlindungan Sosial di Indonesia: Menggagas Model Jaminan Sosial Universal Bidang Kesehatan (Poverty and social protection in Indonesia: Developing Universal Model of Social Security in Health), Bandung: Alfabeta.

[23] Teresa Cunha Ferreira, (2018), Bridging planned conservation and community empowerment: Portuguese case studies, Journal of Cultural Heritage Management and $\begin{array}{llllll}\text { Sustainable Development, } & \text { Vol. } & 8 & \text { Issue: } & 2, & \text { pp.179- }\end{array}$ 193,https://doi.org/10.1108/JCHMSD-05-2017-0029

[24] Yuswar ZB, Hermien Triyowati, Yolanda Masnita, (2014), The Analysis of Potency and Impact of Z.I.S Distribution on The Prosperity of Dhuafa, proceeding, ISBN: 978602-14687-1-5, http://aicie.org/2014/

[25] Yuswar ZB, Hermien Triyowati, Yolanda Masnita, (2015), Zakat, Infak, Sedekah dan Akuntansinya serta Potensinya dalam Meningkatkan Kesejahteraan Rakyat Miskin 
(Zakat, Infaq, Alms and their Accounting and Its Potential in Improving the Welfare of the Poor, Books, Trisakti University publisher, ISSN: 978-602-9463-51-4

\section{Appendix}

\begin{tabular}{|l|r|r|r|r|r|r|r|r|r|}
\hline & Matrix Correlation \\
\hline & ZCD & EYS & MYS & Lifex & GRDP & Unemp & IDI & dSMEs & POV \\
\hline ZCD & 1 & .020 & -.246 & .275 & $.626^{*}$ & -.083 & .292 & $.313^{*}$ & $-.445^{*}$ \\
\hline EYS & .020 & 1 & .075 & -.132 & -.053 & -.205 & .120 & -.219 & .036 \\
\hline MYS & -.246 & .075 & 1 & $.416^{*}$ & -.134 & .090 & $.394^{*}$ & -.092 & -.251 \\
\hline Lifex & .275 & -.132 & $.416^{*}$ & 1 & $.525^{*}$ & $.573^{*}$ & $.598^{*}$ & .017 & $-.497^{*}$ \\
\hline GRDP & $.626^{*}$ & -.053 & -.134 & $.525^{*}$ & 1 & $.365^{*}$ & -.014 & -.033 & -.129 \\
\hline Unemp & -.083 & -.205 & .090 & $.573^{*}$ & $.365^{*}$ & 1 & .078 & -.117 & .117 \\
\hline IDI & .292 & .120 & $.394^{*}$ & $.598^{*}$ & -.014 & .078 & 1 & .074 & $-.676^{*}$ \\
\hline dMSEs & $.313^{*}$ & -.219 & -.092 & .017 & -.033 & -.117 & .074 & 1 & -.066 \\
\hline POV & $-.445^{*}$ & .036 & -.251 & $-.497^{*}$ & -.129 & .117 & $-.676^{*}$ & -.066 & 1 \\
\hline$* *$ Correlation is significant at the 0.01 level (2-tailed). \\
*Correlation is significant at the 0.05 level (2-tailed).
\end{tabular}

